NBER WORKING PAPER SERIES

\title{
SURVIVAL OF THE BEST FIT: COMPETITION FROM LOW WAGE COUNTRIES AND THE (UNEVEN) GROWTH OF US MANUFACTURING PLANTS
}

\author{
Andrew B. Bernard \\ J. Bradford Jensen \\ Peter K. Schott \\ Working Paper 9170 \\ http://www.nber.org/papers/w9170 \\ NATIONAL BUREAU OF ECONOMIC RESEARCH \\ 1050 Massachusetts Avenue \\ Cambridge, MA 02138 \\ September 2002
}

We thank Rob Feenstra, Gordon Hanson, and Bruce Blonigen for helpful suggestions. The research in this paper was conducted at the Center for Economic Studies. Research results and conclusions expressed are those of the authors and do not necessarily indicate concurrence by the Bureau of the Census or by the National Bureau of Economic Research. The paper has not undergone the review the Census Bureau gives its official publications. It has been screened to insure that no confidential data are revealed. The views expressed herein are those of the authors and not necessarily those of the National Bureau of Economic Research.

(C) 2002 by Andrew B. Bernard, J. Bradford Jensen, and Peter K. Schott. All rights reserved. Short sections of text, not to exceed two paragraphs, may be quoted without explicit permission provided that full credit, including $(\mathrm{C}$ notice, is given to the source. 
Survival of the Best Fit: Competition from Low Wage Countries and the (Uneven)

Growth of US Manufacturing Plants

Andrew B. Bernard, J. Bradford Jensen, and Peter K. Schott

NBER Working Paper No. 9170

September 2002

JEL No. F11, F14, L25, L60

\section{ABSTRACT}

We examine the relationship between import competition from low wage countries and the reallocation of US manufacturing from 1977 to 1997. Both employment and output growth are slower for plants that face higher levels of low wage import competition in their industry. As a result, US manufacturing is reallocated over time towards industries that are more capital and skill intensive. Differential growth is driven by a combination of increased plant failure rates and slower growth of surviving plants. Within industries, low wage import competition has the strongest effects on the least capital and skill intensive plants. Surviving plants that switch industries move into more capital and skill intensive sectors when they face low wage competition.

Andrew B. Bernard

Tuck School of Business

Dartmouth College

100 Tuck Hall

Hanover, NH 03755

andrew.b.bernard@dartmouth.edu

and NBER
J. Bradford Jensen

Center for Economic Studies

Bureau of the Census

8905 Presidential Parkway

Suite 206

Upper Marlboro, MD 20772

and University of Maryland

John.Bradford.Jensen@census.gov

Peter K. Schott

Yale School of Management

135 Prospect Street

New Haven, CT 06520

and NBER

peter.schott@yale.edu 


\section{Introduction}

This paper is about the effect of international trade on the reallocation of activity within US manufacturing. Two trends have dominated this sector over the past 30 years. First, the manufacturing share of employment has fallen sharply while the manufacturing share of real output has fallen far less. Second, the composition of industries within manufacturing has tilted towards the production of capital and skill intensive sectors: T-shirts and televisions are out, peripherals and pharmaceuticals are in. International trade is a prime suspect in these trends. Indeed, as the US has dropped its trade barriers, low wage countries like China and India have begun exporting to the US many of the more labor-intensive products it formerly produced at home. This sort of product cycling - where the US moves out of televisions as developing countries gain the know-how and market access needed to move in - is a key feature of standard trade models. Given their cost disadvantages, it is virtually impossible for US firms in the most labor intensive industries to survive head-to-head competition with firms from the world's most labor abundant economies.

In this paper we address three simple questions. First, is employment and output growth disproportionately lower for US manufacturing plants that face increasing import competition from the poorest countries? Second, in the face of such competition, do plants grow more quickly if they are more capital and skill intensive? Finally, is there evidence that US firms change their product mix in response to low wage competition? Thus, rather than focusing on whether overall imports result in job loss or output declines, we seek evidence of a reallocation of manufacturing away from plants and industries which are theoretically most at risk from low wage imports.

Our analysis of a comprehensive set of US manufacturing plants from 1977 to 1997 yields results that are both strong and intuitive. First, we find that employment and output grow more slowly for plants in industries facing higher levels of low wage competition. Second, we find that higher plant capital and skill intensity mitigate the effect of low wage industry competition. These findings are a combination of two trends. The first is differential growth across surviving plants. The second is a positive correlation between plant death and the level of competition in its associated industry. 
We also examine plants that switch industries over time to gauge the extent to which plants alter their product mix in response to low wage competition. Consistent with the hypotheses of standard trade theory, we find that the average capital and skill intensity of destination industries exceeds the capital and skill intensity of the industries left behind. In addition, plants leaving industries which face higher levels of low wage import competition are more likely to move into sectors with higher capital and skill intensities. Both results are consistent with the idea that plants attempt to upgrade their product mix as low wage competition intensifies.

Our investigation into the reallocation of manufacturing industries is unique in two respects. First, we gauge the degree of low wage competition in an industry via the share of total import value and the share of industry products originating in countries with less than 5\% of US per capita GDP. These measures have several advantages over traditional measures of import competition. Most important, they focus on where imports originate rather than their magnitude. In addition, they measure competition in terms of both product value and within-industry product diversity, an important consideration given the coarseness of industry aggregates.

We focus on import competition from the poorest countries precisely because imports from these countries represent the cleanest test of the predictions of endowment-based trade theory. These countries also represent the fastest growing component of total imports to the US, increasing their share of the US market more than 6-fold from 1972-1992.

Our analysis is also unique in that it focuses on plants rather than industries, an important advantage given the significant heterogeneity of plants within the same industry. This variation can affect a plant's susceptibility to industry-level competition. Variation in factor input intensity, for example, can signal variation in product mix: if the most capital and skill intensive plants in Optical Instruments produce microscopes rather than magnifying glasses, they may compete less directly with Optical Instrument firms from labor abundant countries. By considering both plant and industry characteristics, we provide a more complete analysis of the link between employment, output and international trade.

This paper is related to research in international trade and labor economics that studies the effects of imports on employment. The earliest of these efforts, which are generally restricted to just one or a few indus- 
tries over a relatively short period of time, find little or no association between international competition and employment growth (e.g. Krueger 1980; Grossman 1987; Mann 1988). More recent efforts, examining larger sets of industries, however, have found relatively strong links between employment growth and either import penetration or changes in import price indexes. Freeman and Katz (1991), for example, find that a 10\% increase in import penetration coincides with a $5 \%$ decline in employment in their study of 428 four-digit Standard Industrial Classification (SIC) industries during 1958 to 1984. Revenga (1992), on the other hand, uses an instrumental variables approach to mitigate endogeneity concerns and reports employment declines of roughly $3 \%$ in response to a $10 \%$ drop in import prices. Research by Sachs and Shatz (1994) on the factor content of 131 out of 140 three digit SIC manufacturing industries suggests that roughly $6 \%$ of the decline in manufacturing employment between 1978 and 1990 is due to imports from a large set of developing countries. We find that an increase of 10 percentage points in the share of industry imports from low wage countries lowers employment growth at the average plant by 1.3 percentage points per year.

Our research also relates to various studies of the attributes and postemployment experience of workers who lose their jobs in mass layoffs and plant closures (Kletzer 2000). Consistent with our findings, these workers tend to be less skilled than the average worker, and disproportionately drawn from manufacturing industries.

The remainder of the paper is organized as follows. The next section summarizes the theoretical framework guiding our analysis and outlines testable hypotheses. Sections 3 and 4 describe how we construct our low wage import competition measures and summarize our dataset. Section 5 presents the main results on manufacturing reallocation and industry switching. Section 6 concludes.

\section{Theory}

A key implication of standard trade models is that a country's product mix is a function of its level of development. In the factor proportions framework, development is measured via relative endowments: relatively

capital and skill abundant countries like the US are expected to produce a 
more capital and skill intensive mix of goods than relatively labor abundant countries like China. The standard diagram for depicting this equilibrium is displayed in the left panel of Figure 1, which illustrates the relative development of two countries - the US and China - in a world of two factors and multiple goods. Each good is represented by a Leontief-technology unit value isoquant; goods prices identify relative wages, which anchor negatively sloped isocost lines.

In the figure, the US offers high wages relative to capital costs $\left(w_{U S} / r_{U S}\right)$ due to its capital abundance. As a result, US production of labor intensive Apparel and Textiles is unprofitable. The negative profits that would be earned by firms in those sectors can be seen by comparing the amount of capital and labor that can be bought for one dollar in the US versus the amount of capital and labor needed to produce one dollar's worth of Apparel or Textile output. Relatively high capital costs in China, on the other hand, render production of capital intensive Chemicals and Machinery unprofitable in China. Though Figure 1 builds intuition for these relationships using just two factors, results are easily generalized to a world of many factors and goods (Leamer 1987).

Industry reallocation can be driven by the removal of trade barriers. As the US opens its markets to imports from developing countries, the output of the formerly protected industries is expected to decline and eventually disappear. The logic of this reallocation can be seen by comparing the right and left panels of Figure 1. In the right panel, trade barriers result in higher US prices for Apparel and Textiles, represented by unit value isoquants that are closer to the origin (where less capital and labor are required to produce a dollar's worth of output). As trade barriers fall, the US moves toward the equilibrium depicted in the left panel, where as noted above, production of Apparel and Textiles are not viable. It is of course possible for firms in formerly protected industries to survive by improving productivity. On the other hand, the magnitude of productivity gains required to overcome competition from the world's lowest wage countries is considerable and is likely to be confined to industries of medium capital and skill intensity rather than extreme labor intensity.

Consideration of this model leads to several predictions about plant performance and plant and industry characteristics. Our primary interest is in the prediction of the theory about the response of plant growth to 
low wage competition. We focus on responses by the average plant in the industry as well as the interaction between low wage competition and plant input characteristics.

Hypothesis 1 Plant growth is decreasing in industries where low wage countries have comparative advantage.

This cross-industry hypothesis follows directly from Figure 1. It predicts that plant growth will be lower where the share of imports from low wage countries is higher. ${ }^{1}$

Hypothesis 2 Within industries experiencing competition from low wage countries, plant growth is increasing in plant capital and skill intensity and plant productivity.

This is a within-industry hypothesis that assumes plant input techniques are correlated with underlying product variation: labor intensive plants produce labor intensive goods most likely to be in direct competition with firms from low wage countries. This view of plant input intensities controls for the arbitrary coarseness of four digit SIC industry aggregates. Schott (2002a) documents a positive correlation across countries between the techniques used to manufacture goods and the prices they command in the US market. As a result, we expect higher capital and skill intensity within industries to mitigate industry competition: within the textile industry, for example, manufacturing should shift toward capital intensive Gore-Tex and away from labor intensive cotton.

\section{Measuring Low Wage Import Competition}

Following Schott (2002b), we construct three measures of low wage country competition at the industry level using product-level import data compiled by Feenstra (1996). An important attribute of these measures is their emphasis on where imports originate rather than the overall level of

\footnotetext{
${ }^{1}$ The strong prediction of the model is that imports from low wage countries will completely eliminate the affected plants and industries.
} 
import activity. The first measure, referred to as the value share or $V S H$, captures low wage country competition in value terms and is computed as

$$
V S H_{i}=\frac{\sum_{c \in L} M_{i c}}{\sum_{c \in C} M_{i c}},
$$

where $M_{i c}$ is US import value of industry $i$ from country $c$ in year $t$ and $L$ is the set of low wage countries in year $t .^{2}$ This measure yields the share of an industry's import value that comes from low wage countries. It does not measure the level of imports from low wage countries. ${ }^{3}$ In our empirical work below, we avoid problems with annual fluctuations in this measure by averaging across inter-Census years: the value share for industry $i$ in Census year $t$ is the average of $V S H_{i}$ across years $t-5$ to $t-1$.

The second competition measure, referred to as the product share or $P S H$, is a coverage ratio measuring the fraction of products within an industry that originate in low wage countries,

$$
P S H_{i}=\frac{N_{i}^{L}}{N_{i}},
$$

where $N_{i}$ is the total number of products in industry $i$ and $N_{i}^{L}$ is the number of products imported from at least one low wage country in that industry. Together, $\mathrm{VSH}_{i}$ and $P S H_{i}$ capture industry competition along both the intensive (size) and extensive (breadth) margins. Our definition of a product is the ten digit Harmonized System (HS) level of aggregation, which is the most finely-detailed import data available. The average number of products across manufacturing industries ranges from 21 in 1972 to 33 in 1992. As with the value share, we use five year averages of the product share in our empirical work below.

Finally, we construct an interaction of our two share measures to capture the overall level of import competition from low wage countries,

$$
P V S H_{i}=P S H_{i} \times V S H_{i} .
$$

\footnotetext{
${ }^{2}$ Throughout the paper, we refer to value share and product share as measures of competition from low wage countries. We recognize that this may be a non-standard use of the term "competition" which usually denotes pressure on prices and we discuss the relationship between our measures and import prices below.

${ }^{3}$ The total volume of imports may also be of interest and we consider a measure of import penetration in the robustness section below.
} 
We are able to compute each competition measure for 385 of 459 SIC4 industries. ${ }^{4}$

We classify countries as low wage if they have less than $5 \%$ of US per capita GDP. ${ }^{5}$ A list of countries fitting this criteria is reported in Table 1. We choose a $5 \%$ cutoff for several reasons. Most important, it represents the cohort of countries most likely to have an effect on US manufacturing plants given the theory laid out in Section 2. Second, though this cohort of countries is responsible for a relatively small level of exports, it accounts for a significant share of US import growth among the broader set of less developed countries. ${ }^{6}$ Third, it provides a relatively stable set of countries over the 1972 to 1992 period we consider.

One potential concern with using the $5 \%$ cutoff is that our measures are correlated with industry value and product shares for other groups of countries that are more important competitors for US firms. In fact, the value and product shares for our definition of low wage countries are relatively uncorrelated with analogous shares for alternate country cohorts. Table 2 displays the correlation of low wage value and product shares with the value and product shares for the OECD, the Asian Tigers and three definitions of "middle income" countries. As indicated in the first column, low wage value shares are negatively correlated with OECD value shares and have low or negative correlations with the remaining cohorts. Correlations are higher for the product share measure, particularly with respect to the Asian Tigers and the lower "middle income" cohorts. However, the third column reveals that overall competition, as measured via the interaction of intensive and extensive margins, is again negatively correlated with the shares of the OECD and high "middle income" countries and only weakly correlated with the other three groups.

As indexes of import competition, $V S H$ and $P S H$ have significant ad-

\footnotetext{
${ }^{4}$ Mapping products to four digit industries involves the use of several imperfect concordances (Schott 2002b). These imperfections reduce the number of industries for which $\mathrm{VSH}_{i}$ and $\mathrm{PSH}_{i}$ can be calculated.

${ }^{5}$ We use current real exchange rates to perform the conversion to US $\$$ rather than a PPP exchange rate. For such low levels of income the use of current rates does not change the list of countries below the cutoff, while using PPP exchange rates sharply limits the available number of countries and years due to the lack of available data.

${ }^{6}$ Among countries with less than $30 \%$ of US per capita GDP, the cohort of countries with less than $5 \%$ experienced the largest increase in import share, by far, between 1972 and 1992.
} 
vantages and some disadvantages over existing measures. An important advantage is that they are largely robust to shocks affecting both domestic production and imports. Import penetration ratios (defined as imports divided by domestic production plus imports less exports) can induce negative correlation with plant output and employment growth due to the presence of domestic production in the denominator. Two additional advantages are that $V S H$ and $P S H$ are available for very disaggregate industries over a long time horizon, and that they capture competition in terms of both value and product coverage.

An important disadvantage of $V S H$ and $P S H$ is that they are not measures of true competition because they track low wage country presence rather than their effect on prices. However, Feenstra (1994) shows that while $V S H_{i}$ is not a price index, it can vary inversely to the industry import price index that one would want to observe. ${ }^{7}$ Existing import price indexes are less than ideal for a couple of reasons. First, in terms of practical usage, they are available only for a small number of years and only for very aggregate industries. Second, they generally ignore the impact of new varieties, which can bias them upwards and understate competition (Feenstra 1994). The inclusion of the $P S H_{i}$ measure allows us to indirectly measure the introduction of new varieties from low wage countries.

\footnotetext{
${ }^{7}$ Feenstra (1994) shows that $V S H_{i}$ can be related to import prices. Suppose the minimum cost of obtaining one unit of services from variety $j$ from country $n$ is given by the CES cost function $c(\mathbf{p}, J, N)=\left[\sum_{j \in J} \sum_{n \in N} b_{j n} p_{j n}^{1-\sigma}\right]^{\frac{1}{\sigma-1}}$, where $\sigma$ denotes an elasticity of substitution greater than unity; $\mathbf{p}$ is the varieties price vector; $b_{j n}>0$ denotes a taste parameter for variety $j$ from country $n$ which may be interpreted as variety quality; and $J$ and $N$ are the sets of varieties and countries, respectively. If $N^{H}$ is the (constant) set of high wage countries in both periods and the taste parameter for high wage countries is time invariant, the Diewert (1976) exact price index $(P)$ between periods $t$ and $t-1$ can be written $P\left(\mathbf{p}_{t}, \mathbf{p}_{t-1}, J, N\right)=\frac{c\left(p_{t}, N_{t}\right)}{c\left(p_{t-1}, N_{t-1}\right)}=\frac{c\left(p_{t}, N^{H}\right)}{c\left(p_{t}, N^{H}\right)}\left[\frac{1-V S H_{t}}{1-V S H_{t-1}}\right]^{\frac{1}{\sigma-1}}$, where the first term on the right hand side is the rich-country only cost ratio. As indicated by the second term on the right hand side, increases in the presence of low wage countries via higher $V S H$ drive down the price index. The intuition for this relationship is that unavailable low wage country varieties effectively have an infinite price, and this price falls as $V S H$ rises and low wage country varieties become available.
} 


\subsection{Low Wage Competition over Time and across Industries}

Table 3 summarizes the distribution of the value share and product share measures from 1972 to 1992. Each column of the table reports the mean and standard deviation of the competition measures across industries over a five year period. ${ }^{8}$ The average industry imported $38.7 \%$ of its products from at least one low wage country between 1972 and 1976 . In each period, the share of products imported from low wage countries is significantly higher than the accompanying value share of imports.

Both measures of low wage competition have roughly doubled over our sample. Between 1972 and 1992, VSH in the average industry grew from $3.4 \%$ to $7.5 \%$ while the average $P S H$ increased to $62.1 \%$ from $38.7 \%$. Most of the increase in product penetration occurred in the latter part of the sample with over half coming during 1982 to 1986. Similarly, over two thirds of the increase in value penetration occurred in the final sample period, 1987 to 1991. In general, a high level of product penetration for an industry is positively correlated with subsequent increases in the value share.

Table 4 reports the correlation between our low wage import share measures, import penetration, and real import price changes over the 1972 to 1992 sample. Because import price changes are computed for three digit SIC industries, the final row of the table is based upon three digit SIC versions of all the competition measures. In general, though $V S H$ and $P S H$ covary, the correlation of these measures with import penetration and real import price changes is quite low, increasing our confidence in their ability to pick up new aspects of import competition.

We show how the value share and product share measures vary across industries according to their input intensity in Figure 2. The figure contains four endowment triangles (Leamer 1987). ${ }^{9}$ Industries can be plotted in the simplex according to their input intensity vectors (i.e. according to where these vectors pierce the simplex). Four representative industries are displayed, Gloves, Socks, Chemicals and Instruments. Relatively production worker intense Gloves (SIC 2381) is located nearer the production worker vertex than more skill intense (i.e. non-production worker intense)

\footnotetext{
${ }^{8}$ The periods are constructed to precede each of the four panels in the plant-level data.

${ }^{9}$ The (Leamer) triangles are the two dimensional simplexes that result from intersecting a three dimensional factor space with a plane.
} 
Instruments (SIC 3812). Note that industry locations change over time as input intensities evolve. All four industries become more non-production worker intensive over time.

Low wage import competition over the endowment triangle is estimated via a kernal density across the four digit SIC industry observations in each year. Intensity of competition is indexed by shading, with light and dark being the respective lower and upper bounds. The shading is consistent across all four plots.

The figure shows that, between 1972 and 1992, the growth of competition as measured by the value share is concentrated in industries that use production workers intensively. Capital intensive manufacturing, such as Chemicals (SIC 2819), faces very low import values from low wage countries. Competition as measured by product shares from low wage countries is much more intense and far-reaching. Already high among production worker intense industries in 1972, it spreads all the way up to the nonproduction worker intensive portion of the triangle by 1992 . This movement of competition across manufacturing input intensity space provides intuition for our results below. Over time, US manufacturing is reallocating away from the labor intensive industries facing increasingly higher competition from low wage countries and towards capital intensive industries where low wage countries do not have comparative advantage.

\section{Plant Data}

The data in this paper come from two sources. In addition to the import competition measures described above, the plant data come from the Longitudinal Research Database (LRD) of the Bureau of the Census. We use data from the Censuses of Manufactures (CM) starting in 1977 and conducted every fifth year through 1997. The sampling unit for the Census is a manufacturing establishment, or plant, and the sampling frame in each Census year includes detailed information on inputs, output, and ownership on all establishments. ${ }^{10}$

\footnotetext{
${ }^{10}$ While the LRD does contain basic information on small plants (so-called Administrative records), we do not include them in this study due to the lack of information on inputs other than total employees. Since our competition measures start only in 1972, we must start our sample with the 1977 Census.
} 
From the Census, we obtain plant characteristics including location, capital stock at the plant, the quantity of and the wages paid to nonproduction and production workers, total value of shipments, total value of exports, energy and purchased material inputs, the number of products produced at the plant, the primary four digit Standard Industrial Classification (SIC), and age.

In constructing our sample, we make several modifications to the basic data. First, we drop any industry whose products are categorized as 'not elsewhere classified'. These 'industries' are typically catch-all categories for a group of heterogenous products. In practice, this corresponds to any industry whose four digit SIC code ends in '9' and SIC 39xx. Second, we combine some 4-digit SIC industries in order to match the import competition measures, leaving us with 337 industry categories. We use information on all manufacturing establishments in the 1977, 1982, 1987, and 1992 Censuses but must drop any establishment that does not report one of the input or output measures. We are left with $443,000+$ observations on $245,000+$ plants across the four panels.

\subsection{Plant Productivity}

As noted above, productivity gains can play an important role in a plant's ability to survive low wage competition. As a result, we compute a TFP measure for each plant and include it as a control in our regression analysis. As is well known, accurately measuring multi-factor productivity at the plant is quite difficult. Since we have only single observations for many of the establishments in the sample, we are constrained in our choice of productivity measures. We estimate a simple five input production function in logs for each industry and year,

$\ln Y_{i p t}=\beta_{i t}^{0}+\beta_{i t}^{1} \ln P_{i p t}+\alpha_{i t}^{2} \ln N P_{i p t}+\beta_{i t}^{3} \ln K_{i p t}+\beta_{i t}^{4} \ln B_{i p t}+\beta_{i t}^{5} \ln M_{i p t}+\epsilon_{i p t}$

where $\mathrm{Y}$ is gross output of the plant in year $t, P$ and $N P$ are the number of production and non-production workers at the plant, $K$ is the book value of machinery and equipment, $B$ is the book value of buildings and structures and $M$ is the value of purchased inputs and energy. Recognizing that we are unable to adequately control for the co-movement of markups and productivity, or the co-movements of variable inputs and productivity, we 
use $\epsilon_{i p t}$ as our measure of plant total factor productivity. By construction the measure is mean zero for each industry in each period.

\subsection{Plant Factor Input Intensities}

We measure plant capital intensity via the log of the ratio of the capital stock to total employment $(K / L)$. Skill intensity is harder to measure in the LRD as there is relatively little information on the characteristics of the workforce. We use two measures of skill: the plant wage for production workers and that for non-production workers. Variation in these measures should capture differences in the average quality of the workers at the plant if not their relative quantities. In our robustness checks, we explore another measure of skill, the ratio of non-production to production workers $(N P / P)$, where the sum of these workers is the total labor force $(L)$.

\subsection{Plant Survival}

We examine employment and output growth on a subset of surviving plants as well as the full sample of surviving and dying plants. In performing regressions on surviving plants, we control for plant survival via a standard Heckman correction (Heckman 1976). The included mills ratio is an estimate of the probability of plant survival. Following Bernard and Jensen (2002), we estimate the probability of plant death as a function of a number of plant, firm, and industry characteristics. ${ }^{11}$ To assist in identification of the selection equation we include measures of plant product mix diversity, firm characteristics such as dummies for US multinational ownership, recent ownership changes and multi-plant status, and industry level measures industry sunk cost of entry, and relative regional specialization and diversity. The effects of entry costs and the additional plant and firm characteristics on plant deaths are large and significant allowing us to separately identify the selection equation from the growth rate regressions in the next section. As in Bernard and Jensen (2002), we find that plant survival is positively associated with capital and skill intensity and negatively associated with low wage competition. In addition, within industries

\footnotetext{
${ }^{11}$ Complete results from the selection probit are available on request from the authors. Alternatively, see Table 8, column 1 of Bernard and Jensen (2002).
} 
that face high levels of low wage competition, plants with low capital and skill levels are more likely to close.

\section{Empirical results}

We compute and analyze two different growth rates. The first, due to Davis and Haltiwanger (1992), is the change in plant employment inclusive of plant births and deaths,

$$
g_{p, t: t+5}^{D H}=\frac{1}{5} \cdot \frac{E_{p, t+5}-E_{p t}}{\frac{1}{2}\left(E_{p, t+5}+E_{p t}\right)}
$$

where $E_{p t}$ represents employment of plant $p$ in year $t$. This growth rate is equal to 2 for new plants and -2 for dying plants. Because we cannot observe the characteristics of plants prior to their birth, we are unable to include birth observations in our empirical specifications below. As a result, $g_{p, t: t+5}^{D H}$ represents a lower bound on employment loss: within an industry job creation at newly born plants will offset some or all of this loss.

Our second growth rate is the annualized log difference of employment at continuing plants,

$$
g_{p, t: t+5}^{\ln }=\left(\ln E_{p, t+5}-\ln E_{p t}\right) / 5 .
$$

The results that follow are based on regressions of employment and output growth on vectors of plant characteristics $\left(\mathbf{Z}_{p t}\right)$, industry competition measures $\left(\mathbf{C}_{i t}\right)$ and interactions of plant characteristics with industry competition $\left(\mathbf{X}_{i p t}\right)$,

$$
g_{p, t: t+5}^{D H, \ln }=\mathbf{Z}_{p t}^{\prime} \boldsymbol{\alpha}+\mathbf{C}_{i t}^{\prime} \boldsymbol{\beta}+\mathbf{X}_{i p t}^{\prime} \boldsymbol{\gamma}+\boldsymbol{\varepsilon}_{p t} .
$$

The plant characteristics, $\mathbf{Z}_{p t}$, include the logs of employment, age, productivity $(T F P)$, capital intensity $(K / L)$ and skill intensity (ln Pwage ln $N P$ wage). Numerous studies on mean reversion in plant employment growth have documented the relationship between initial size and age and subsequent changes in employment (e.g. Hall 1987 and Blonigen and Tomlin 2001). While we are not interested in testing Gibrat's law per se, we 
include the log of initial employment as well as plant age in all our specifications. $^{12}$

We control for plant capital and skill intensity as well as plant productivity. The trade theories in Section 2 suggest that plant growth in the US should be increasing in plant skill intensity and plant capital intensity. Employment and output growth is expected to be lower in labor intensive plants and higher in capital and skill intensive plants for comparative advantage reasons. Second, plant growth should be increasing in plant productivity. Plants can survive head-to-head competition with low wage country firms via productivity improvements. It is also possible that more capital and skill intensive plants have experienced relative productivity gains over labor intensive plants. ${ }^{13}$

The industry competition measures, $\mathbf{C}_{i t}$, are $P S H, V S H$ and their interaction, $P V S H$. The final vector, $\mathbf{X}_{i p t}$, contains the interacted competition variable, $P V S H$, interacted with the logs of productivity and plant capital, as well as skill intensity. For regressions examining growth at continuing plants, we include the mills ratio discussed in Section 4.3.

\subsection{Plant Employment and Competition from Low Wage Countries}

The first column of Table 5 summarizes the association between employment growth and plant and industry characteristics on the full set of plants in the sample. These OLS regressions use $g_{p, t: t+5}^{D H}$ as the dependent variable.

Conditioning on plant characteristics, both measures of low wage competition as well as their interaction are significant at the $1 \%$ level. Taken together, these coefficients imply an overall negative relationship between low wage competition and plant growth offering strong support for Hypothesis 1. Figure 3 illustrates how employment growth varies across industries as a function of low wage competition in 1977 and 1992. For each industry, the coefficients in the first column of Table 5 are used to estimate employ-

\footnotetext{
${ }^{12}$ The LRD does not record the precise start year for any plant. Instead, we only know the first year the plant appears in a Census of Manufactures starting with the 1963 Census. Our measure of plant age is the difference between the current year and the first recorded Census year. Plants that are in their first Census are given an age of zero.

${ }^{13}$ Closed economy models of heterogeneous firms such as Olley and Pakes (1996) also predict faster growth for more capital intensive and more productive plants.
} 
ment growth. The percentage point deviation of this growth from that of an industry facing the average level of $P S H$ and $V S H$ is then plotted, yielding the surface displayed in the figure. ${ }^{14}$ Industries are denoted by ' 77 ' or ' 92 ' depending upon the year. The surface slopes down toward the front of the figure, where competition is most intense.

As indicated, plants in industries with above average competition experience sharp declines in employment growth. In 1992, for example, the industry facing the highest level of competition, Leather Gloves (SIC 3151), experienced employment growth that was 15 percentage points below that of the average industry. Alternatively an industry with value and product shares one standard deviation above the mean would have employment growth 2.2 percentage points lower.

An alternate view of the relationship between employment growth and low wage competition - this time with respect to the median industry is provided in Table 6 . There, industries are split into cohorts depending upon how much their estimated employment growth deviates from the industry facing median competition. Consistent with the increase in competition over time noted in Figures 2 and 3, the distribution of deviations is moving towards lower estimated growth over time. In 1977, for example, most industries had modest exposure to low wage competition, with the result that 266 of 331 industries had estimated employment growth that deviates less than 0.5 percentage points from the median. Even so, 8\% (30) of industries faced enough competition from low wage countries to have their growth rates lowered by more than 0.5 percentage points, while $4 \%$ of industries (14), including Textile Bags (SIC2393) and Leather Gloves (SIC3151), had their growth rates lowered by more than -1.5 percentage points. By 1992, many more industries faced substantial competition from low wage countries. As a result, more than twice as many industries (77) experienced growth rates at least 0.5 percentage points below the median, while the number of industries experiencing decreases of 1.5 percentage points relative to the median tripled, to 53 .

The second column of Table 5 adds interactions of plant characteristics with $P V S H_{i}$. Consistent with Hypothesis 2, we find that capital intensive plants have significantly higher growth rates in industries facing low wage

\footnotetext{
${ }^{14}$ The industry with average levels of low wage competition in 1977 and 1992 shows up as a zero on the surface.
} 
competition relative to their labor intensive counterparts. The interactions with plant skill intensity are also positive but not significant. Interestingly, the productivity interaction is not significant and has the 'wrong' sign.

The final column of Table 5 includes plant fixed effects, which absorb all time-invariant plant attributes that may be correlated with slower growth and high levels of low wage competition. ${ }^{15}$ These 'within-plant' results are even stronger than results in the second column of the table. Controlling for plant effects, increases in industry low wage competition have an even more limiting effect on employment growth. The interaction between import competition and plant characteristics confirms that import competition from low wage countries has different effects on plants depending on their input characteristics. Plants with high capital intensity and high skill intensity grow relatively faster when facing low wage competition. The interactions with all three measures of capital and skill are positive and significant. The effect of the interaction with plant productivity remains negligible.

Table 7 examines employment growth across the subset of 323,000+ plants that survive from one Census to the next. These regressions use $g_{p, t: t+5}^{\ln }$ as the growth rate and include the selection correction described in Section 4.3. Here too, we find that low wage competition continues to have an overall negative relationship with plant employment growth. The final two columns of Table 7 include interactions of plant attributes with industry competition as well as a specification with plant fixed effects. The magnitude of the low wage competition measures is increased while the capital and skill interactions are positive and significant in the fixed effect specification.

\subsection{Plant Output and Competition from Low Wage Countries}

The strong negative relationship between low wage competition and plant employment growth has two possible interpretations. The first is that firms facing low wage competition shrink (or die). The second is that such firms respond to competition by substituting away from relatively expensive US labor and toward relatively inexpensive US skill or capital. In the second scenario, plant employment could decline even as output remained

\footnotetext{
${ }^{15}$ Including just industry fixed effects does not change the conclusions.
} 
the same or even increased. To differentiate between these explanations, we investigate the relationship between real output growth and competition in Table 8. While we concentrate on the full sample of plants, results for survivors are similar.

Overall, we find that output and employment respond similarly to low wage import competition. The coefficients on $\mathrm{PSH}_{i}, \mathrm{VSH} \mathrm{H}_{i}$ and $\mathrm{PVSH}_{i}$ are significant across all three specifications in Table 8 . In each case, increases in competition are associated with sharp declines in output growth. Indeed, the distribution of estimated industry output growth around the median industry exhibits an even sharper reallocation than is evident with respect to employment growth in Table 6 . While $10 \%$ of the industries faced enough import competition from low wage countries to lower annual relative output growth by at least 0.5 percentage points in 1977 , the number more than tripled, to $31 \%$, by $1992 .{ }^{16}$ Furthermore, the number of industries whose output growth was more than 1.5 percentage points below the median also increased dramatically over the period, from $5 \%$ up to $18 \%$ of all industries. While relative output declines were frequent across labor intensive sectors such as Apparel (SIC 23xx), relative output increases were common among capital intensive sectors such as Chemicals (SIC 28xx).

The second and third columns of Table 8 include interactions of plant factor intensities and productivity with $P V S H_{i}$. Here too, results with respect to capital and skill intensity support the hypotheses of standard trade theory: capital and skill intensive plants have significantly higher growth rates in industries facing low wage competition relative to their labor intensive counterparts. Unlike the employment specifications, the interaction of low wage competition with plant productivity is positive, and significant in one specification.

There are two main explanations for the strongly negative association between plant growth and low wage competition. Our preferred explanation is that the imports from low wage countries are a driving force in reducing the survival prospects and overall growth of plants in the affected industries. This view emphasizes the role of international trade in shaping the reallocation of US manufacturing within and across industries. An alternative explanation is that the US is becoming relatively capital and

\footnotetext{
${ }^{16}$ Annualized output growth for the industry facing median competition was $0.03 \%$ in $1977-81$ and $-0.2 \%$ in $1992-97$.
} 
skill abundant, perhaps due to rapid skill-biased technological change, and is leaving low capital and low skill sectors which are then being supplied by low wage countries. From this perspective, international trade, i.e. the location of imports, is responding to changes in the US economy. In order to distinguish between these two views, all our specifications are run as the change in employment (or output) from year $t$ to $t+5$ on the average levels of low wage competition in years $t-5$ to $t-1$. For our findings to be consistent with an endogenous response of low wage imports, low wage countries would have to be entering industries that they expect to decline 5 to 10 years later: a hypothesis we find unlikely but cannot test directly. Instead, we find more likely the conclusion that increasing imports from low wage countries are a major component in the reallocation of US manufacturing.

\subsection{Robustness}

In this section we examine the robustness of our results to two specification changes. First, we re-estimate the model using the ratio of nonproduction to production workers $(N P / P)$ as a measure of skill intensity in place of the wage measures. Second, we ask whether the relationship between low wage competition and plant growth remains after controlling for a standard measure of overall import penetration. To conserve space, we focus in this section on the plant fixed effect specification.

The first column of Table 9 repeats the results from column 3 of Table 5 to facilitate comparison. Column 2 of Table 9 reports the results using the ratio of non-production to production workers, $N P / P$, rather than the wages to control for plant skill intensity. While the effects of low wage competition and capital intensity are unchanged, $N P / P$ has a negative coefficient in both its level and interaction. There are several possible explanations for this result. First, the US may not have a comparative advantage in skill-intensive production. Second, $N P / P$ may be a poor proxy for the skill-intensity of production relative to low wage countries. We suspect, given the strength of the results using the two wage measures, that the relative skill intensity of production across plants is not well captured by the raw quantity ratio.

The final column of Table 9 includes ordinary industry import penetration in addition to our measures of low wage import competition. This penetration is associated negatively with employment growth, but it does 
not eliminate the effect of the low wage competition measures. Indeed, the significance and magnitude of $P S H$ and $V S H$ are quite similar to the values reported in the base regression in the first column. This result is important because it emphasizes the fact that where imports originate has a significant effect on manufacturing reallocation that is independent of the overall level of imports.

\subsection{Industry Switching}

Until now we have focused entirely on the employment and output growth of plants facing import competition from low wage countries. In this section, we consider another possible response by domestic plants to foreign competition, changes in their product mix. For (detailed) products that are both exported from the US and imported to the US from low wage countries, Schott (2002b) finds that the US export unit values are significantly higher than import unit values of the low wage countries. One explanation of this finding is that US producers of low unit value products shut down in the face of the low wage competition. Our evidence, and that of Bernard and Jensen (2002), indicate that low skill, low capital plants grow more slowly, primarily due to their increased probability of shutdown. To the extent that capital and skill intensities are correlated with within-industry product differentiation, plant exit could explain US unit value upgrading. Another possibility is that plants alter their output mix to avoid low wage competition, either by vertically differentiating their products or by moving into a product subject to less competition from poor countries. In both cases, such switches should involve capital or skill deepening.

Unfortunately, the LRD does not track plant output using the same level of detail as our trade data. We can observe the primary 4-digit SIC code of the plant. Many, or even most, potential product changes would occur within an industry and thus not affect the 4-digit SIC code of the plant. However, some fraction of potential product upgrading may involve industry switching. ${ }^{17}$ For surviving plants, we look at switches in the SIC

\footnotetext{
${ }^{17}$ Bernard and Jensen (2001) find that plants which switch industries have a higher probability of being exporters. This movement into more viable products is consistent with the view that plants escape low wage country competition by upgrading their product mix.
} 
code reported by the plants and ask if they are related in a systematic way to low wage competition.

The 4-digit SIC code reported by the plant corresponds to the classification for the product(s) that comprises the majority of the plant's output. If a plant is producing roughly equal amounts of two products, small changes in output in the Census years could result in changes in the reported SIC code. This element of random variation in classification changes should bias us against finding any systematic changes in capital and skill intensity across the old and new industries. We test whether switching plants move to more capital and skill intensive industries. We compare the capital and skill intensities in the old and new industries in year $t$, both unconditionally and as a function of low wage import competition. We expect to find higher capital and skill intensities in the new industries, especially for plants that face higher competition from low wage countries.

On average, $7.8 \%$ of the surviving plants in our sample report changes in their 4-digit SIC code across neighboring Censuses, i.e. over a five year period. For those switching plants, we look at the average input intensities for the old and new industries in Table 10. If firms are trying to reduce their exposure to low wage import competition through switching, we would expect them to move to more capital and skill intensive industries. On average, for the $25,000+$ plants that switch, they do move to more capital and skill-intensive industries. The physical capital-intensity of destination industry in year $t$ is $1.1 \%$ higher than that of the original industry in year $t$. Similarly, non-production and production wages are significantly higher in the new industries, by $0.7 \%$ and $0.1 \%$ respectively, although the latter is not significant. Finally, we look at the measures of low wage competition in the old and new industries for switching plants. As expected, we find that plants switch to industries with lower levels of $V S H_{i}(2.1 \%$ lower and significant at the $10 \%$ level) and $P S H_{i}$ (0.2\% lower but not significant).

Next, we regress the difference in industry factor intensity for switching plants on our low wage competition measures,

$$
\Delta f_{s d t}=c+C_{s t}^{\prime} \beta+\varepsilon_{s d t}
$$

where $\Delta f_{s d t}$ is the percentage difference in the factor intensity of the average plant in the destination industry $d$ in year $t$ relative to the factor intensity of the average plant in the starting industry $s$ in year $t$. Table 11 reports the 
results for capital intensity, non-production wages and production wages. Increasing import competition from low wage countries has a strong positive relationship with all three measures of factor intensity changes. Plants that switch from an industry with high levels of low wage import competition move to industries with higher capital and skill intensities than the average switching plant. For example, a plant leaving an industry at the $75^{\text {th }}$ percentile of low wage import competition lands in a new industry that is $8.7 \%$ more capital intensive and pays $1.4 \%$ higher non-production wages, and $2.8 \%$ higher production wages. For the average switching plant, the new industry is $1.1 \%$ more capital intensive and pays $0.7 \%$ and $0.1 \%$ higher non-production and production wages respectively. These results suggest that surviving US firms employ a variety of responses to increased import competition from low wage countries.

\section{Conclusions}

Imports from low income countries were the fastest growing component of US trade from 1972 to 1997, increasing far more rapidly than total imports. The rapid growth included both the value of shipments and the variety of products from those countries. In this paper we consider the role of import competition from low wage countries in changing the nature of the US manufacturing sector over the last 30 years. We find that low wage competition has been a powerful force for reallocation within and across US industries. In particular, the major effect of import competition from low wage countries has been to accelerate the process of capital deepening and skill upgrading across and within US manufacturing industries.

The restructuring induced by low wage competition takes three related forms: plant deaths, plant growth and product changes. Greater competition from low wage countries increases plant failure rates across industries. Within industries, plants that are the best 'fit', i.e. the most capital and skill-intensive, are the least likely to close when low wage competition rises. Beyond plant shutdowns, we find that both employment and output growth rates are significantly lower at plants that face high levels of low wage import competition. Relative to the average plant, a 10 percentage point rise in low wage import shares decreases employment and output growth by 1.3 and 1.6 percentage points per year, respectively. Again, within sectors, 
growth is even slower for plants that are the most labor-intensive, i.e. the poorest fit.

Even within plants we see an impact of imports from low income countries. We provide evidence that some plants respond to low wage competition by changing their product mix. Plants that switch industries move to sectors that are more capital and skill intensive than the industries they leave behind. This is particularly true for plants that leave sectors with high levels of low wage competition.

This paper only begins to examine the role of increased trade with low income countries on firms and industries in the US. Additional research is also needed on the response by US firms to such competition in the form of investment, workforce upgrading, and product innovation. Given the differential impact across industries and plants, we expect to find significant regional effects of low wage competition including changes in industry structure, wage levels and inequality. 


\section{References}

Bernard, Andrew B. and J. Bradford Jensen. 2001. Why Some Firms Export. NBER Working Paper \# 8349.

Bernard, Andrew B. and J. Bradford Jensen. 2002. The Deaths of Manufacturing Plants. NBER Working Paper \# 9026.

Blonigen, Bruce A. and KaSaundra Tomlin. 2001. Size and Growth of Japanese Plants in the United States. International Journal of Industrial Organization, vol. 19, no. 6, pp. 931-52.

Davis, Steven J. and John Haltiwanger. 1992. Gross Job Creation, Gross Job Destruction, and Employment Reallocation. Quarterly Journal of Economics 107(3):819-863.

Diewert, W. Erwin. 1976. Exact and Superlative Index Numbers. Journal of Econometrics 4:115-145.

Feenstra, Robert C. 1996. US Imports 1972-1994: Data and Concordances. NBER Working Paper 5515.

Feenstra, Robert C. 1994. New Product Varieties and the Measurement of International Prices. American Economic Review 84:157-177.

Freeman, Richard and Lawrence Katz. 1991. Industrial Wage and Employment Determination in an Open Economy, in Immigration, Trade and the Labor Market, edited by John M. Abowd and Richard B. Freeman. Chicago: University of Chicago Press.

Grossman, Gene. 1987. The Employment and Wage Effects of Import Competition. Journal of International Economic Integration 2(1):1-23.

Hall, Bronwyn H. 1987. The Relationship Between Firm Size and Firm Growth in the US Manufacturing Sector. Journal of Industrial Economics 35(4):583-606.

Heckman, J. 1976. The Common Structure of Statistical Models of Truncation, Sample Selection and Limited Dependent Variables, and a Simple Estimator for Such Models. The Annals of Economic and Social Measurement 5: 475-492. 
Kletzer, Lori G. 2000. Trade and Job Loss in U.S. Manufacturing, 1979-94. in Robert Feenstra, ed., The Impact of International Trade on Wages. University of Chicago Press, Chicago.

Krueger, Anne, O. 1980. "Impact of Foreign Trade on Employment in US Industry" edited by J. Bleck and B. Hindley, Current Issues in Commercial Policy and Diplomacy. New York: St Martin's Press.

Leamer, Edward E. 1987. Paths of Development in the Three-Factor, nGood General Equilibrium Model. Journal of Political Economy 95:961999.

Mann, Catherine L. 1988. The Effects of Foreign Competition in Prices and Quantities on Employment in Import-Sensitive Industries. International Trade Journal II (Summer):409-444.

Revenga, Ana L. 1992. Exporting Jobs? The Impact of Import Competition on Employment and Wages in U.S. Manufacturing. Quarterly Journal of Economics 107(1):255-284.

Sachs, Jeffrey D. and Howard J. Shatz. 1994. Trade and Jobs in U.S. Manufacturing. Brookings Papers on Economic Activity 1994(1):1-69.

Schott, Peter K. 2002a. Endowment-Driven Product Specialization in International Trade. Yale School of Management mimeo.

Schott, Peter K. 2002b. Moving Up and Moving Out: US Product-Level Exports and Competition from Low Wage Countries. Yale School of Management mimeo. 

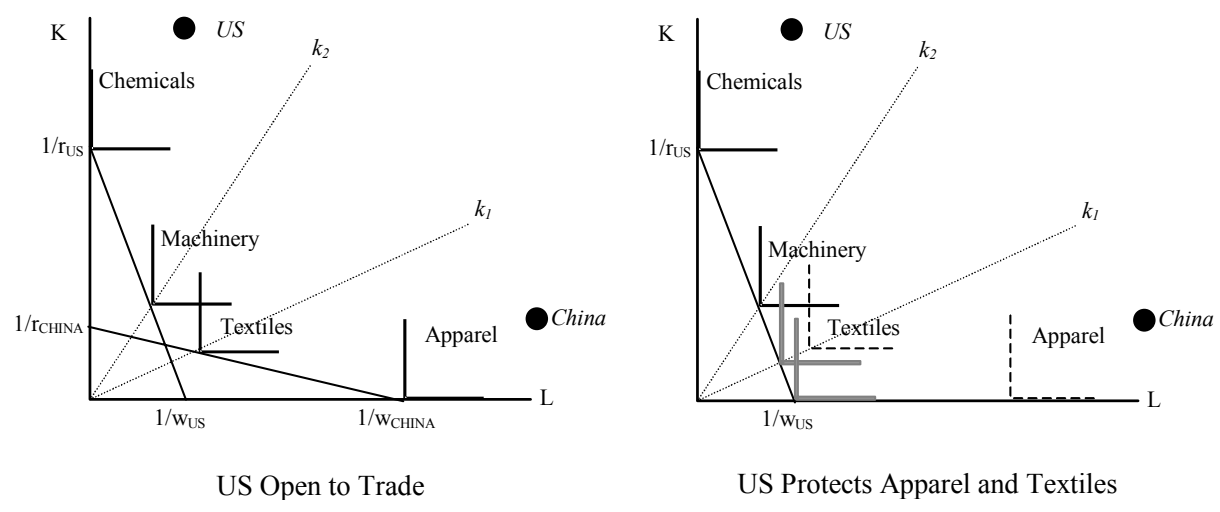

Figure 1: Specialization in the Factor Proportions Framework 


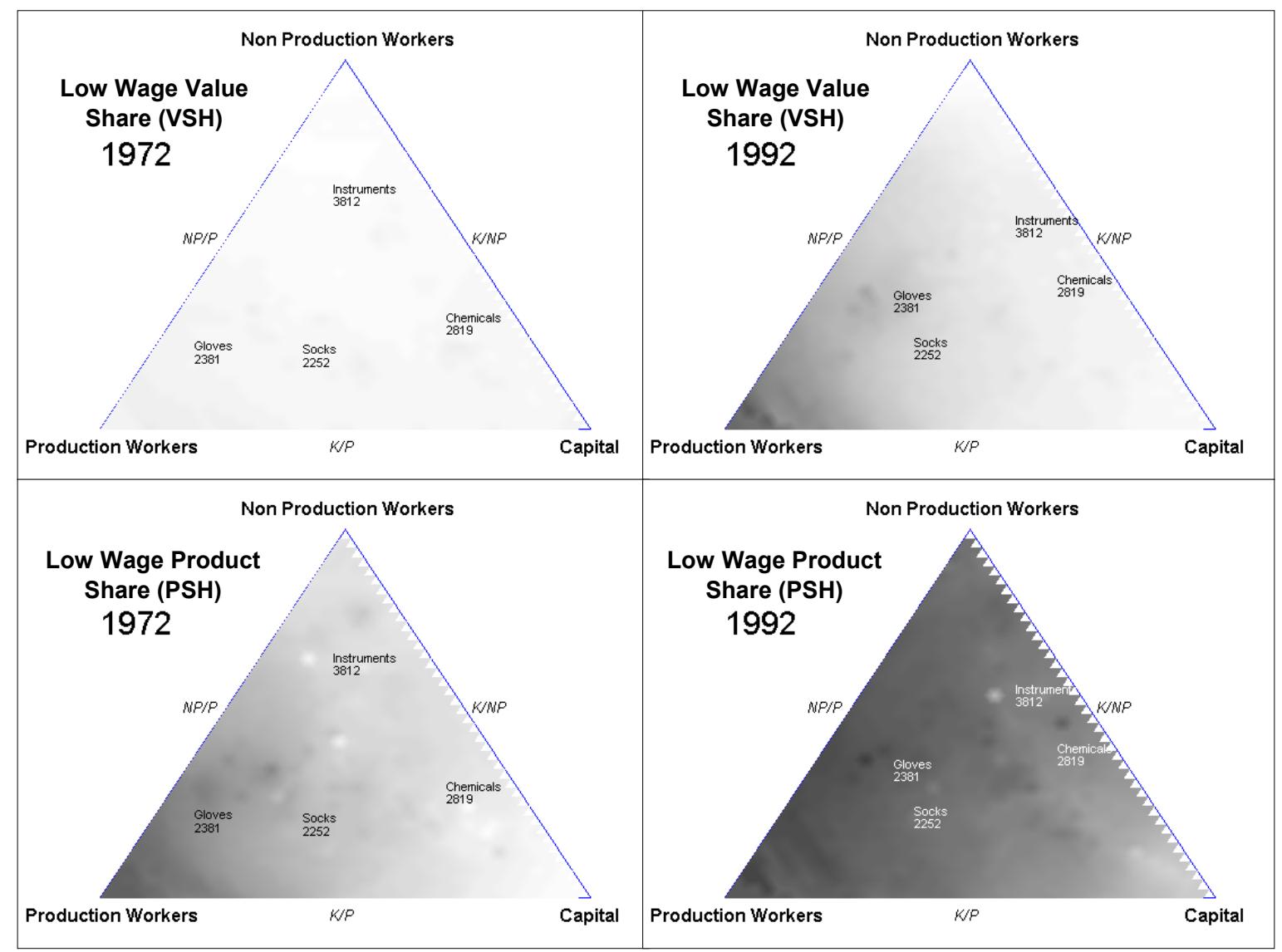

Notes: Endowment triangles display level of low wage country competition for 1972 and 1992. Each triangle is a simplex defined by intersecting a plane with a three dimensional factor space. An industry's location in the triangle is fixed by its skill and capital intensities. The shading of the surface is estiamted via a kernal density across the four digit SIC industry observations for each year. Darker coloration corresponds to higher levels of competition. Shading is consistent across all four plots to facilitate comparison. Four representative industries are plotted in each simplex; their location shifts over time as production techniques evolve.

Figure 2: Value Share and Product Share Competition from Low Wage Countries - Variation in Industry Input Space 


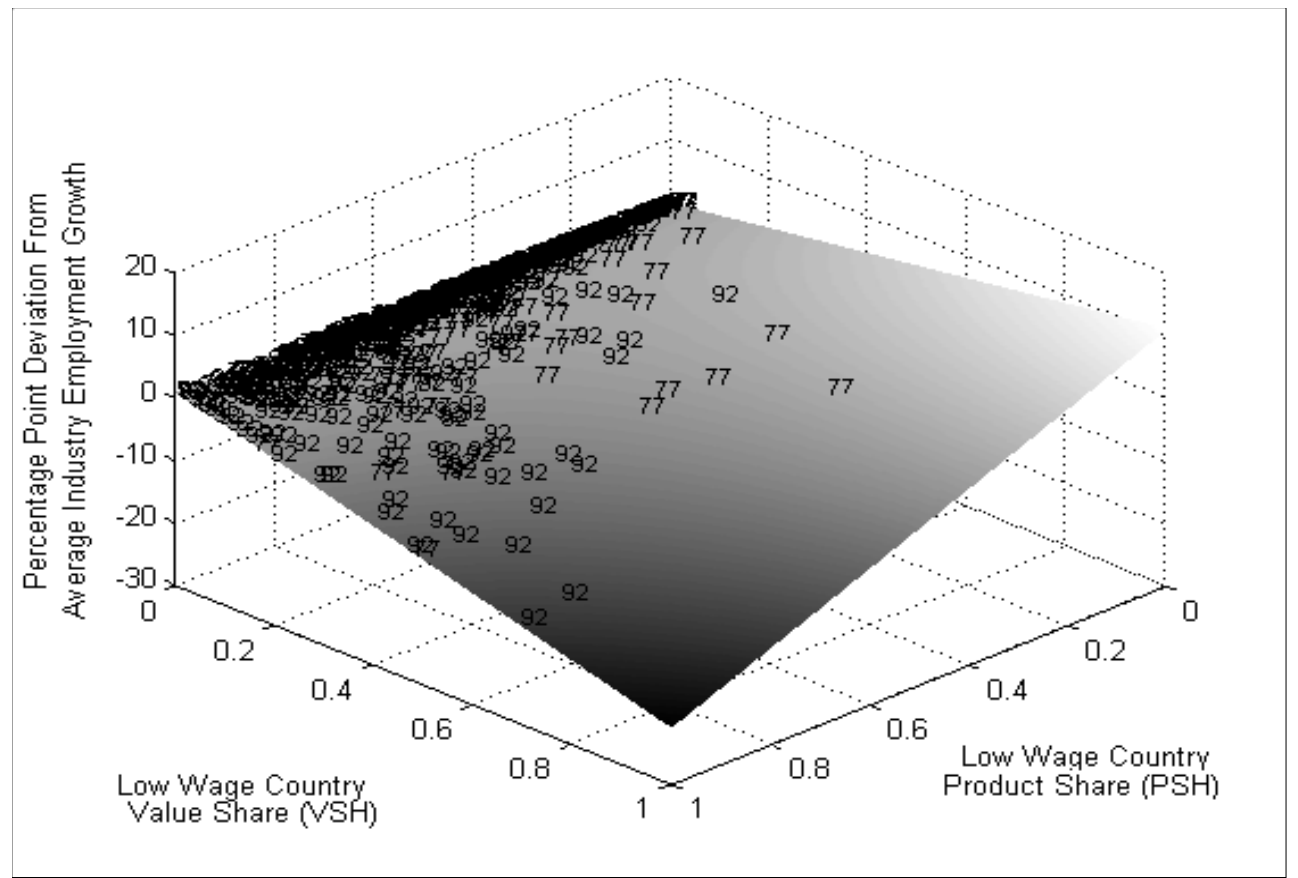

Notes: Figure plots industries' employment growth deviation (in percentage points) from the employment growth of the industry facing the average level of low wage competition. Data for both 1977 and 1992 are displayed and noted via either '77' or '92'. Industry employment growth as a function of VSH and NSH are estimated using the regression coefficients in the first column of Table 5 .

Figure 3: Plant Employment Growth Relative to Industry Facing Average Low Wage Competition (All Plants) 


\begin{tabular}{|l|l|l|l|}
\hline Afghanistan & China & India & Pakistan \\
Albania & Comoros & Kenya & Rwanda \\
Angola & Congo & Lao PDR & Samoa \\
Armenia & Equatorial Guinea & Lesotho & Sao Tome \\
Azerbaijan & Eritrea & Madagascar & Sierra Leone \\
Bangladesh & Ethiopia & Malawi & Somalia \\
Benin & Gambia & Maldives & Sri Lanka \\
Bhutan & Georgia & Mali & St. Vincent \\
Burkina Faso & Ghana & Mauritania & Sudan \\
Burundi & Guinea & Moldova & Togo \\
Cambodia & Guinea-Bissau & Mozambique & Uganda \\
Central African Rep & Guyana & Nepal & Vietnam \\
Chad & Haiti & Niger & Yemen \\
\hline
\end{tabular}

Table 1: Low Wage Countries 1972 to 1992

\begin{tabular}{|l|c|c|c|}
\hline \multirow{2}{*}{ Alternate Country Group } & \multicolumn{3}{|c|}{$\begin{array}{c}\text { Correlation with Low Wage Country Group } \\
\text { (I.e. Countries with less than 5\% of US PCGDP) }\end{array}$} \\
\cline { 2 - 4 } & VSH & PSH & PVSH \\
\hline OECD Countries & -0.65 & 0.19 & -0.58 \\
\hline Asian Tigers & 0.14 & 0.70 & 0.13 \\
\hline $\begin{array}{l}\text { Countries with 5-25\% of } \\
\text { US PCGDP }\end{array}$ & 0.15 & 0.65 & 0.09 \\
\hline $\begin{array}{l}\text { Countries with 25-50\% } \\
\text { of US PCGDP }\end{array}$ & -0.03 & 0.56 & -0.03 \\
\hline $\begin{array}{l}\text { Countries with 50-75\% } \\
\text { of US PCGDP }\end{array}$ & -0.23 & 0.38 & -0.20 \\
\hline
\end{tabular}

Notes: Each cell displays the correlation of value and product share competition for countries with less than 5\% of US per capita GDP with the shares for an alternate group of countries. Correlations are computed across 387 SIC4 industries and four Census years (1977, 1982, 1987 and 1992). Correlation coefficients control for time effects. The OECD cohort excludes members added after 1972 (e.g. Mexico and Korea). The Asian Tiger cohort consists of Hong Kong, Korea, Singapore and Taiwan. Examples of countries in the last three cohorts (which exclude the Tigers) in 1992 are Mexico, New Zealand and Spain, respectively. See text for definitions of VSH, PSH and PVSH.

Table 2: Similarity of Competition Members Across Different Country Groups 


\begin{tabular}{|l|cc|cc|cc|cc|}
\hline & \multicolumn{2}{|c|}{$1972-1976$} & \multicolumn{2}{|c|}{$1977-1981$} & \multicolumn{2}{c|}{$1982-1986$} & \multicolumn{2}{c|}{$1987-1991$} \\
\cline { 2 - 9 } Competition Measure & Mean & $\begin{array}{c}\text { Standard } \\
\text { Deviation }\end{array}$ & Mean & $\begin{array}{c}\text { Standard } \\
\text { Deviation }\end{array}$ & Mean & $\begin{array}{c}\text { Standard } \\
\text { Deviation }\end{array}$ & Mean & $\begin{array}{c}\text { Standard } \\
\text { Deviation }\end{array}$ \\
\hline $\begin{array}{l}\text { Low Wage Product } \\
\text { Share (PSH) }\end{array}$ & 0.387 & 0.253 & 0.427 & 0.248 & 0.544 & 0.237 & 0.621 & 0.237 \\
\hline $\begin{array}{l}\text { Low Wage Value Share } \\
\text { (VSH) }\end{array}$ & 0.034 & 0.082 & 0.035 & 0.071 & 0.048 & 0.086 & 0.075 & 0.115 \\
\hline
\end{tabular}

Notes: Competition measures are recorded at the four digit SIC level.

Table 3: Import Competition Summary Statistics

\begin{tabular}{|l|c|c|c|}
\hline Competition Measure & $\begin{array}{c}\text { Low Wage } \\
\text { Product Share } \\
\text { (PSH) }\end{array}$ & $\begin{array}{c}\text { Low Wage Value } \\
\text { Share (VSH) }\end{array}$ & Import Penetration \\
\hline $\begin{array}{l}\text { Low Wage Value Share } \\
\text { (VSH) }\end{array}$ & 0.31 & & \\
\hline Import Penetration & 0.17 & 0.17 & \\
\hline $\begin{array}{l}\text { Change in Real Import } \\
\text { Price Index }\end{array}$ & -0.01 & -0.01 & -0.02 \\
\hline
\end{tabular}

Notes: Import Price Indexes are recorded at the three digit SIC level, are deflated by the US CPI and are unavailable for 1972 to 1976. Correlations for the first three rows of the table are based upon four digit SIC industries. Correlations in the final row of the table are based upon three digit SIC industries. Correlation coefficients control for time effects.

Table 4: Import Competition Correlation Matrix 


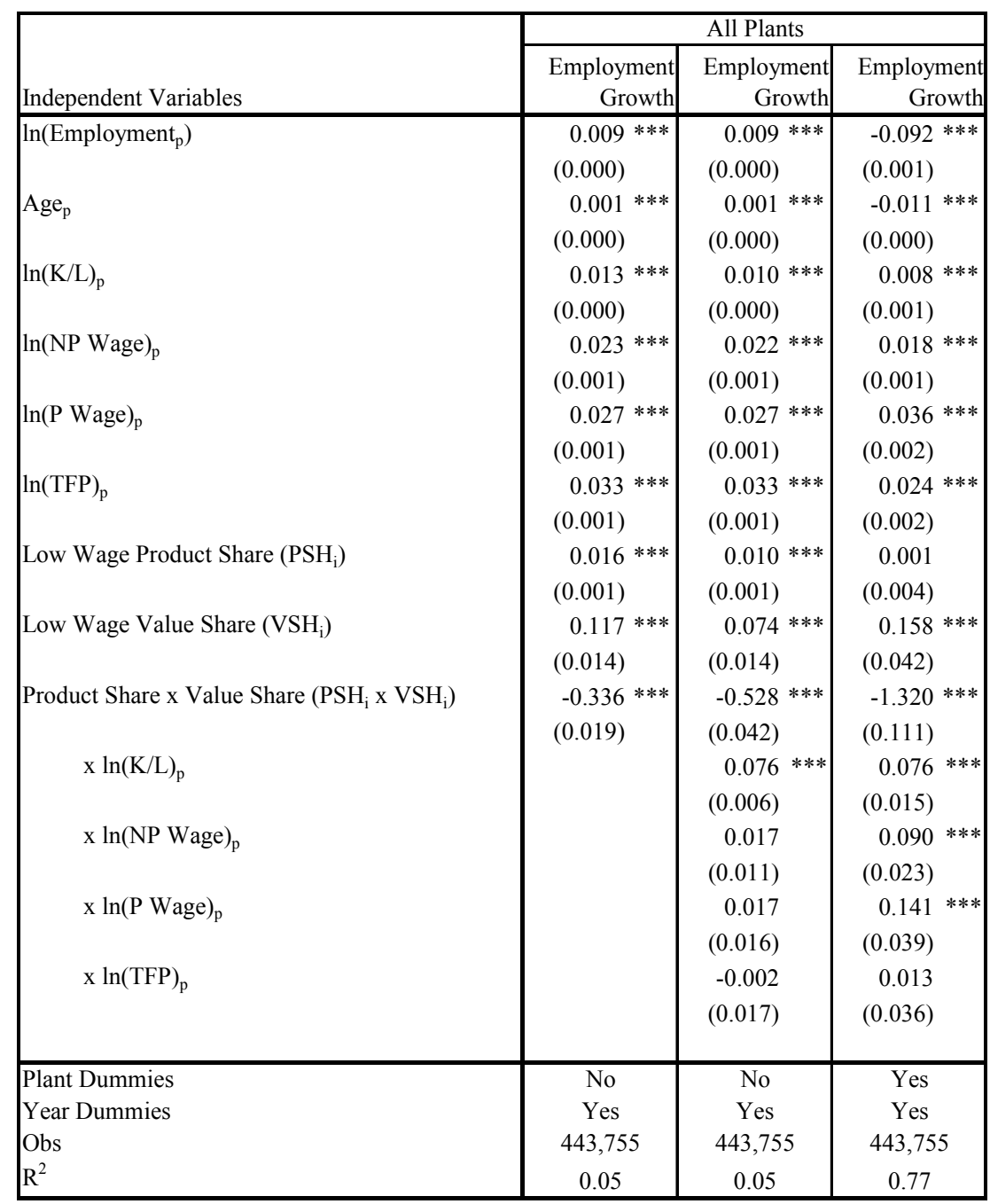

Notes: Standard errors are in parentheses and are heteroskedastic-consistent and adjusted for clustering at the plant level. ***Significant at the $1 \%$ level; **Significant at the $5 \%$ level; *Significant at the $10 \%$ level.

Table 5: Employment Growth and Low Wage Competition (All Plants) 


\begin{tabular}{|c|c|c|}
\hline $\begin{array}{c}\text { Percentage Point Employment Growth } \\
\text { Deviation From Industry Facing Median Low } \\
\text { Wage Country Competition }\end{array}$ & \multicolumn{2}{|c|}{$\begin{array}{c}\text { Share of Industries } \\
\text { (All Plant Sample) }\end{array}$} \\
\hline$>1.5 \%$ & 1977 & 092 \\
{$[0.5 \%$ to $1.5 \%)$} & 11 & 7 \\
{$[0 \%$ to $0.5 \%)$} & 40 & 43 \\
\hline$[-0.5 \%$ to $0 \%)$ & 42 & 28 \\
{$[-1.5 \%$ to $-0.5 \%)$} & 4 & 9 \\
$<-1.5 \%$ & 4 & 13 \\
\hline
\end{tabular}

Notes: Each cell reports the number of industries with the indicated deviation in employment growth (in pecentage points) from the industry facing median competition from low wage countries. Relative growth for industry $i$ is computed using using the regression coefficients in the first column of Tables 5 and 6, respectively. Numbers may not sum to 100 due to rounding.

Table 6: Effects of Low Wage Competition on Employment Growth 


\begin{tabular}{|c|c|c|c|}
\hline \multirow[b]{2}{*}{ Independent Variables } & \multicolumn{3}{|c|}{ Surviving Plants } \\
\hline & $\begin{array}{r}\text { Employment } \\
\text { Growth }\end{array}$ & $\begin{array}{r}\text { Employment } \\
\text { Growth }\end{array}$ & $\begin{array}{l}\text { Employmen } \\
\text { Growth }\end{array}$ \\
\hline $\ln \left(\right.$ Employment $\left._{\mathrm{p}}\right)$ & $\begin{array}{l}-0.012 * * * \\
(0.000)\end{array}$ & $\begin{array}{l}-0.012 * * * \\
(0.000)\end{array}$ & $\begin{array}{l}-0.157 \text { *** } \\
(0.001)\end{array}$ \\
\hline $\mathrm{Age}_{\mathrm{p}}$ & $\begin{array}{l}-0.001 * * * \\
(0.000)\end{array}$ & $\begin{array}{l}-0.001 * * * \\
(0.000)\end{array}$ & $\begin{array}{l}-0.001 * * * \\
(0.000)\end{array}$ \\
\hline $\ln (\mathrm{K} / \mathrm{L})_{\mathrm{p}}$ & $\begin{array}{l}0.011 * * * \\
(0.000)\end{array}$ & $\begin{array}{l}0.011 \text { *** } \\
(0.000)\end{array}$ & $\begin{array}{l}0.006 \text { *** } \\
(0.001)\end{array}$ \\
\hline $\ln (\mathrm{NP} \text { Wage })_{\mathrm{p}}$ & $\begin{array}{l}0.018 * * * \\
(0.001)\end{array}$ & $\begin{array}{l}0.019 \text { *** } \\
(0.001)\end{array}$ & $\begin{array}{l}0.012 * * * \\
(0.001)\end{array}$ \\
\hline $\ln (\text { P Wage })_{\mathrm{p}}$ & $\begin{array}{l}0.017 \text { *** } \\
(0.001)\end{array}$ & $\begin{array}{l}0.016^{* * *} \\
(0.001)\end{array}$ & $\begin{array}{l}0.022 * * * \\
(0.002)\end{array}$ \\
\hline $\ln (\mathrm{TFP})_{\mathrm{p}}$ & $\begin{array}{l}0.022 * * * \\
(0.001)\end{array}$ & $\begin{array}{l}0.023 * * * \\
(0.001)\end{array}$ & $\begin{array}{l}0.014 \text { *** } \\
(0.002)\end{array}$ \\
\hline Low Wage Product Share $\left(\mathrm{PSH}_{\mathrm{i}}\right)$ & $\begin{array}{l}0.024 * * * \\
(0.001)\end{array}$ & $\begin{array}{l}0.023 * * * \\
(0.001)\end{array}$ & $\begin{array}{r}0.004 \\
(0.003)\end{array}$ \\
\hline Low Wage Value Share $\left(\mathrm{VSH}_{\mathrm{i}}\right)$ & $\begin{array}{l}0.134 \text { *** } \\
(0.010)\end{array}$ & $\begin{array}{l}0.126^{* * *} \\
(0.011)\end{array}$ & $\begin{array}{r}0.045 \\
(0.028)\end{array}$ \\
\hline Product Share $\mathrm{x}$ Value Share $\left(\mathrm{PSH}_{\mathrm{i}} \mathrm{x} \mathrm{VSH}_{\mathrm{i}}\right)$ & $\begin{array}{l}-0.180 * * * \\
(0.015)\end{array}$ & $\begin{array}{l}-0.277 * * * \\
(0.047)\end{array}$ & $\begin{array}{l}-0.731 * * * \\
(0.106)\end{array}$ \\
\hline $\mathrm{x} \ln (\mathrm{K} / \mathrm{L})_{\mathrm{p}}$ & & $\begin{array}{r}0.002 \\
(0.005)\end{array}$ & $\begin{array}{l}0.023 * * \\
(0.011)\end{array}$ \\
\hline$x \ln (\text { NP Wage })_{p}$ & & $\begin{array}{l}-0.017 \\
(0.011)\end{array}$ & $\begin{array}{c}0.040 * \\
(0.021)\end{array}$ \\
\hline$x \ln (P \text { Wage })_{p}$ & & $\begin{array}{l}0.061^{* * *} \\
(0.016)\end{array}$ & $\begin{array}{l}0.145 * * * \\
(0.032)\end{array}$ \\
\hline $\mathrm{x} \ln (\mathrm{TFP})_{\mathrm{p}}$ & & $\begin{array}{l}-0.025 \\
(0.017)\end{array}$ & $\begin{array}{r}0.004 \\
(0.029)\end{array}$ \\
\hline Mills Ratio $_{p}$ & $\begin{array}{l}0.013 * * * \\
(0.002)\end{array}$ & $\begin{array}{l}0.012 * * * \\
(0.002)\end{array}$ & $\begin{array}{l}0.020 \text { *** } \\
(0.003)\end{array}$ \\
\hline $\begin{array}{l}\text { Plant Dummies } \\
\text { Year Dummies } \\
\text { Obs } \\
\mathrm{R}^{2}\end{array}$ & $\begin{array}{c}\text { No } \\
\text { Yes } \\
323,601 \\
0.05\end{array}$ & $\begin{array}{c}\text { No } \\
\text { Yes } \\
323,601 \\
0.05\end{array}$ & $\begin{array}{c}\text { Yes } \\
\text { Yes } \\
323,601 \\
0.76\end{array}$ \\
\hline
\end{tabular}

Notes: Standard errors are in parentheses and are heteroskedastic-consistent and adjusted for clustering at the plant level. ***Significant at the $1 \%$ level; **Significant at the $5 \%$ level;

*Significant at the $10 \%$ level.

Table 7: Employment Growth and Low Wage Competition (Surviving Plants) 


\begin{tabular}{|c|c|c|c|}
\hline \multirow[b]{2}{*}{ Independent Variables } & \multicolumn{3}{|c|}{ All Plants } \\
\hline & Output & Output & Output \\
\hline $\ln \left(\right.$ Employment $\left.t_{p}\right)$ & $\begin{array}{l}0.015^{* * *} \\
(0.000)\end{array}$ & $\begin{array}{l}0.015 \text { *** } \\
(0.000)\end{array}$ & $\begin{array}{l}-0.074 \text { *** } \\
(0.001)\end{array}$ \\
\hline $\mathrm{Age}_{\mathrm{p}}$ & $\begin{array}{l}0.001 * * * \\
(0.000)\end{array}$ & $\begin{array}{l}0.001 * * * \\
(0.000)\end{array}$ & $\begin{array}{l}-0.007 * * * \\
(0.000)\end{array}$ \\
\hline $\ln (\mathrm{K} / \mathrm{L})_{\mathrm{p}}$ & $\begin{array}{l}0.004 * * * \\
(0.000)\end{array}$ & $\begin{array}{r}0.000 \\
(0.000)\end{array}$ & $\begin{array}{l}-0.027 * * * \\
(0.001)\end{array}$ \\
\hline $\ln (\text { NP Wage })_{\mathrm{p}}$ & $\begin{array}{l}0.020 \text { *** } \\
(0.001)\end{array}$ & $\begin{array}{l}0.019 \text { *** } \\
(0.001)\end{array}$ & $\begin{array}{l}-0.005 * * * \\
(0.002)\end{array}$ \\
\hline $\ln (\mathrm{P} \text { Wage })_{\mathrm{p}}$ & $\begin{array}{l}0.022 * * * \\
(0.001)\end{array}$ & $\begin{array}{l}0.021 \text { *** } \\
(0.001)\end{array}$ & $\begin{array}{l}-0.010 * * * \\
(0.002)\end{array}$ \\
\hline $\ln (\mathrm{TFP})_{\mathrm{p}}$ & $\begin{array}{l}-0.021 * * * \\
(0.001)\end{array}$ & $\begin{array}{l}-0.023 * * * \\
(0.001)\end{array}$ & $\begin{array}{l}-0.098 * * * \\
(0.003)\end{array}$ \\
\hline Low Wage Product Share $\left(\mathrm{PSH}_{\mathrm{i}}\right)$ & $\begin{array}{r}0.001 \\
(0.001)\end{array}$ & $\begin{array}{l}-0.006 * * * \\
(0.001)\end{array}$ & $\begin{array}{c}-0.002 \\
(0.004)\end{array}$ \\
\hline Low Wage Value Share $\left(\mathrm{VSH}_{\mathrm{i}}\right)$ & $\begin{array}{l}0.170 * * * \\
(0.014)\end{array}$ & $\begin{array}{l}0.112 \text { *** } \\
(0.014)\end{array}$ & $\begin{array}{l}0.215 \text { *** } \\
(0.044)\end{array}$ \\
\hline $\begin{array}{l}\text { Product Share } \mathrm{x} \text { Value Share }\left(\mathrm{PSH}_{\mathrm{i}} \mathrm{x} \mathrm{VSH}_{\mathrm{i}}\right) \\
\quad \mathrm{x} \ln (\mathrm{K} / \mathrm{L})_{\mathrm{p}}\end{array}$ & $\begin{array}{l}-0.416 * * * \\
(0.019)\end{array}$ & $\begin{array}{l}-0.618 * * * \\
(0.044) \\
0.108 * * * \\
(0.006)\end{array}$ & $\begin{array}{l}-1.290 * * * \\
(0.121) \\
0.090 * * * \\
(0.016)\end{array}$ \\
\hline$x \ln (\text { NP Wage })_{p}$ & & $\begin{array}{r}0.013 \\
(0.012)\end{array}$ & $\begin{array}{l}0.111^{* * *} \\
(0.026)\end{array}$ \\
\hline$x \ln (P \text { Wage })_{p}$ & & $\begin{array}{r}0.008 \\
(0.017)\end{array}$ & $\begin{array}{c}0.066 * \\
(0.041)\end{array}$ \\
\hline$x \ln (\mathrm{TFP})_{\mathrm{p}}$ & & $\begin{array}{l}0.083^{* * *} \\
(0.019)\end{array}$ & $\begin{array}{r}0.062 \\
(0.044)\end{array}$ \\
\hline Plant Dummies & No & No & Yes \\
\hline Year Dummies & Yes & Yes & Yes \\
\hline Obs & 443,755 & 443,755 & 443,755 \\
\hline $\mathrm{R}^{2}$ & 0.05 & 0.05 & 0.74 \\
\hline
\end{tabular}

Notes: Standard errors are in parentheses and are heteroskedastic-consistent and adjusted for clustering at the plant level. ***Significant at the $1 \%$ level; **Significant at the $5 \%$ level; *Significant at the $10 \%$ level.

Table 8: Output Growth and Low Wage Competition (All Plants) 


\begin{tabular}{|c|c|c|c|}
\hline \multirow[b]{2}{*}{ Independent Variables } & $\begin{array}{c}\text { Base Regression } \\
\text { (Table 5, Column 3) }\end{array}$ & $\begin{array}{l}\text { NP/P for Skill } \\
\text { Intensity } \\
\end{array}$ & Import Penetration \\
\hline & Employment Growth & Employment Growth & Employment Growth \\
\hline $\ln \left(\right.$ Employment $\left._{\mathrm{p}}\right)$ & $\begin{array}{l}-0.092 * * * \\
(0.000)\end{array}$ & $\begin{array}{l}-0.096 * * * \\
(0.001)\end{array}$ & $\begin{array}{l}-0.093 * * * \\
(0.001)\end{array}$ \\
\hline $\mathrm{Age}_{\mathrm{p}}$ & $\begin{array}{l}-0.011 * * * \\
(0.000)\end{array}$ & $\begin{array}{l}-0.011^{* * *} \\
(0.000)\end{array}$ & $\begin{array}{l}-0.011 * * * \\
(0.000)\end{array}$ \\
\hline $\ln (\mathrm{K} / \mathrm{L})_{\mathrm{p}}{ }^{1}$ & $\begin{array}{l}0.008 * * * \\
(0.000)\end{array}$ & $\begin{array}{l}0.011^{* * *} \\
(0.001)\end{array}$ & $\begin{array}{l}0.008 * * * \\
(0.001)\end{array}$ \\
\hline $\ln (\text { NP Wage })_{p}$ & $\begin{array}{l}0.018^{* * *} \\
(0.000)\end{array}$ & & $\begin{array}{l}0.018 * * * \\
(0.001)\end{array}$ \\
\hline $\ln (\text { P Wage })_{\mathrm{p}}$ & $\begin{array}{l}0.036 * * * \\
(0.000)\end{array}$ & & $\begin{array}{l}0.036 * * * \\
(0.002)\end{array}$ \\
\hline $\ln (\mathrm{NP} / \mathrm{P})_{\mathrm{p}}$ & & $\begin{array}{l}-0.006^{* * *} \\
(0.001)\end{array}$ & \\
\hline $\ln (\mathrm{TFP})_{\mathrm{p}}$ & $\begin{array}{l}0.024 * * * \\
(0.000)\end{array}$ & $\begin{array}{l}0.034 * * * \\
(0.002)\end{array}$ & $\begin{array}{l}0.024 * * * \\
(0.002)\end{array}$ \\
\hline Low Wage Product Share $\left(\mathrm{PSH}_{\mathrm{i}}\right)$ & $\begin{array}{r}0.001 \\
(0.000)\end{array}$ & $\begin{array}{r}0.003 \\
(0.004)\end{array}$ & $\begin{array}{r}0.001 \\
(0.004)\end{array}$ \\
\hline Low Wage Value Share $\left(\mathrm{VSH}_{\mathrm{i}}\right)$ & $\begin{array}{l}0.158^{* * * *} \\
(0.000)\end{array}$ & $\begin{array}{l}0.177^{* * *} \\
(0.042)\end{array}$ & $\begin{array}{l}0.142 * * * \\
(0.041)\end{array}$ \\
\hline Product Share $\mathrm{x}$ Value Share $\left(\mathrm{PSH}_{\mathrm{i}} \mathrm{x} \mathrm{VSH}_{\mathrm{i}}\right)$ & $\begin{array}{l}-1.320 * * * \\
(0.000)\end{array}$ & $\begin{array}{l}-0.852 * * * \\
(0.073)\end{array}$ & $\begin{array}{l}-1.202 * * * \\
(0.111)\end{array}$ \\
\hline $\mathrm{x} \ln (\mathrm{K} / \mathrm{L})_{\mathrm{p}}{ }^{1}$ & $\begin{array}{rl}0.076 & * * * \\
(0.000) & \end{array}$ & $\begin{array}{rl}0.111 & * * * \\
(0.013) & \end{array}$ & $\begin{array}{r}0.064 \quad * * * \\
(0.014)\end{array}$ \\
\hline $\mathrm{x} \ln (\mathrm{NP} \text { Wage })_{\mathrm{p}}$ & $\begin{array}{rl}0.090 & * * * \\
(0.000) & \end{array}$ & & $\begin{array}{rl}0.089 & * * * \\
(0.023) & \end{array}$ \\
\hline$x \ln (\text { P Wage })_{p}$ & $\begin{array}{rl}0.141 & * * * \\
(0.000) & \end{array}$ & & $\begin{array}{r}0.1355^{* * *} \\
(0.038)\end{array}$ \\
\hline $\mathrm{x} \ln (\mathrm{NP} / \mathrm{P})_{\mathrm{p}}$ & & $\begin{array}{l}-0.014 \\
(0.015)\end{array}$ & $\begin{array}{l}0.013 \text { *** } \\
(0.036)\end{array}$ \\
\hline $\mathrm{x} \ln (\mathrm{TFP})_{\mathrm{p}}$ & $\begin{array}{r}0.013 \\
(0.000)\end{array}$ & $\begin{array}{r}0.058 \\
(0.036)\end{array}$ & $\begin{array}{r}0.013 \\
(0.000)\end{array}$ \\
\hline Import Penetration & & & $\begin{array}{l}-0.148 * * * \\
(0.014)\end{array}$ \\
\hline $\begin{array}{l}\text { Plant Dummies } \\
\text { Year Dummies } \\
\text { Obs } \\
\mathrm{R}^{2}\end{array}$ & $\begin{array}{c}\text { Yes } \\
\text { Yes } \\
443,755 \\
0.77\end{array}$ & $\begin{array}{c}\text { Yes } \\
\text { Yes } \\
443,755 \\
0.77\end{array}$ & $\begin{array}{c}\text { Yes } \\
\text { Yes } \\
443,755 \\
0.77\end{array}$ \\
\hline
\end{tabular}

Note: ${ }^{1}$ The $\log$ of $\mathrm{K} / \mathrm{P}$ is used in place of $\mathrm{K} / \mathrm{L}$ in column 2. Standard errors are in italics and are heteroskedasticconsistent and adjusted for clustering at the plant level. ***Significant at the $1 \%$ level; **Significant at the $5 \%$ level; *Significant at the $10 \%$ level.

Table 9: Robustness Checks: Wages for Skill and Adding Ordinary Import Penetration, All Plant Sample 


\begin{tabular}{|l|c|c|c|}
\hline & $\begin{array}{c}\text { Mean Difference Across } \\
\text { Plants Between New and Old } \\
\text { Industries }\end{array}$ & $\begin{array}{c}\text { T Statistic } \\
\text { (Mean=0) }\end{array}$ & P Value \\
\hline Capital Intensity (K/L) & $1.1 \%$ & 3.24 & 0.00 \\
Non Production Wage (NP Wage) & $0.7 \%$ & 8.73 & 0.00 \\
Production Wage (P Wage) & $0.1 \%$ & 0.82 & 0.21 \\
VSH & $-2.1 \%$ & 1.65 & 0.09 \\
PSH & $-0.2 \%$ & -0.55 & 0.58 \\
\hline
\end{tabular}

Notes: Calculations based upon a sample of 25,425 plants that switched their four digit SIC industry over the four, five year sample periods.

Table 10: New vs Old Industry Characteristics of Plants Switching SIC4 Industries

\begin{tabular}{|l|c|c|c|}
\hline Independent Variables & K/L Change & $\begin{array}{c}\text { NP Wage } \\
\text { Change }\end{array}$ & $\begin{array}{c}\text { P Wage } \\
\text { Change }\end{array}$ \\
\hline $\begin{array}{l}\text { Low Wage Product } \\
\text { Share (PSH) } \\
\text { Low Wage Value Share } \\
\text { (VSH) } \\
\begin{array}{l}\text { Product Share x Value } \\
\text { Share (PSH x VSH) }\end{array}\end{array} \quad 0.234 * * *$ & $0.020 * * *$ & $0.088 * * *$ \\
\hline $\begin{array}{l}\text { Obs } \\
\mathrm{R}^{2}\end{array}$ & -0.038 & $0.125 * * *$ & 0.017 \\
\hline
\end{tabular}

Notes: ***Significant at the $1 \%$ level; **Significant at the $5 \%$ level; *Significant at the $10 \%$ level. Standard errors are heteroskedastic-consistent and adjusted for clustering at the plant level.

Table 11: Change in Switching Plants' Characteristics and Low Wage Competition 